\title{
HUBUNGAN KADAR HEMOGLOBIN DAN NILAI HEMATOKRIT PADA PEROKOK AKTIF
}

\author{
Relationship Of Hemoglobin Levelsand Hematocrit Value Inactive Smokers \\ Nuradi $^{1}$, Jangga ${ }^{2}$ \\ ${ }^{1}$ Jurusan Analis Kesehatan Poltekkes Kemenkes Makassar \\ ${ }^{2}$ Universitas Mega Rezky Makassar \\ Koresponden : nuradi.poltekkes.mks@gmail.com/085255668090
}

\begin{abstract}
Active smokers are people who smoke actively or continuously. Cigarettes contain toxic substances and have an opiate effect. The presence of tar and free radicals from cigarette smoke can cause erythrocyte hemolysis. Also, the content of cigarette smoke can lead to increased levels of hemoglobin mediated by exposure to carbon monoxide (CO). The large affinity of carbon monoxide against hemoglobin makes it easier for the two compounds to bind together to form carboxyhemoglobin ( $\mathrm{HbCO}$ ), this will also cause an increase in hematocrit value. The purpose of this study was to find out the relationship between hemoglobin levels and hematocrit values in active smokers by using a person correlation test. The number of samples used was 33 samples with purposive sampling techniques. The results showed the average hemoglobin level in smokers was $14.13 \mathrm{~g} /$ $d l$, the average hematocrit value of smokers was $41.58 \%$. The results of the person correlation test between hemoglobin levels and hematocrit values obtained a calculated $r$-value (0.93) > r table (0.344), conclusion $\mathrm{HO}$ rejected and Ha received which means there is a relationship between hemoglobin and hematocrit levels in active smokers. Hemoglobin is positively related to hematocrit.
\end{abstract}

Keywords: Active Smokers, Hemoglobin, Hematocrit

\begin{abstract}
ABSTRAK
Perokok aktif merupakan orang yang merokok secara aktif atau terus menerus. Rokok mengandung bahan beracun dan berefek candu. Adanya tar dan radikal bebas dari asap rokok dapat menyebabkan hemolisis eritrosit. Selain itu, kandungan dari asap rokok dapat menyebabkan peningkatan kadar hemoglobin yang dimediasi oleh paparan karbonmonoksida (CO). Afinitas karbon monoksida yang besar terhadap hemoglobin memudahkan kedua senyawa tersebut untuk saling berikatan membentuk karboksihemoglobin ( $\mathrm{HbCO}$ ), hal ini juga akan menyebabkan peningkatkan pada nilai hematokrit. Tujuan dalam penelitian ini adalah untuk mengetahui hubungan antara kadar hemoglobin dan nilai hematokrit pada perokok aktif dengan menggunakan uji korelasi person. Jumlah sampel yang digunakan sebanyak 33 sampel dengan teknik purposive sampling. Hasil penelitian menunjukkan kadar hemoglobin rata-rata pada perokok adalah $14.13 \mathrm{~g} / \mathrm{dl}$, nilai hematokrit rata-rata para perokok adalah $41.58 \%$. Hasil uji korelasi person antara kadar hemoglobin dan nilai hematokrit didapatkan nilai $r$ hitung $(0.93)>r$ tabel (0.344), kesimpulan $\mathrm{H}_{0}$ ditolak dan $\mathrm{H}_{\mathrm{a}}$ diterima yang berarti terdapat hubungan antara kadar hemoglobin dan hematokrit pada perokok aktif. Hemoglobin berhubungan secara positif terhadap hematokrit.
\end{abstract}

Kata kunci : Perokok Aktif, Hemoglobin, Hematokrit 


\section{PENDAHULUAN}

Rokok adalah hasil olahan tembakau terbungkus termasuk cerutu atau bentuk lainnya yang dihasilkan oleh tanaman Nicotiana tabacum, Nicotiana rustica dan spesies lainnya atau sintesisnya yang mengandung nikotin dan tar dengan atau tanpa bahan tambahan (Amelia dalam Peraturan Pemerintah Republik Indonesia Nomor 19, 2003).

Saat ini jumlah perokok, terutama perokok remaja terus bertambah, khususnya di Negara-negara berkembang. Keadaan ini merupakan tantangan berat bagi upaya peningkatan derajat kesehatan masyarakat. Bahkan organisasi kesehatan dunia atau World Health Organization (WHO) telah memberikan peringatan bahwa dalam decade 2020-2030 tembakau akan membunuh 10 juta pertahun, 20\% diantaranya terjadi di Negara-negara berkembang. Melalui resolusi tahun 1983 organisasi kesehatan dinua (WHO) telah menetapkan tanggal 31 mei sebagai hari bebas tembakau sedunia setiap tahun (Irawati dalam Tandean, 2010).

Beberapa hal yang melatar belakangi seseorang untuk merokok, seperti faktor sosial, faktor farmakologis, dan faktor psikologis. Faktorsosial merupakan faktor eksternal yang mempengaruhi sikap seseorang untuk merokok. Umumnya faktor sosial ini berasal dari lingkungan sekitar, seperti orang tua dan teman sebaya. Dari tinjauan farmakologis, nikotin yang terkandung dalam rokok menimbulkan efek adiktif atau ketergantungan, sehingga seseorang cenderung atau ketagihan untuk terus merokok. Faktor psikologis merupakan faktor Internal yang mempengaruhi seseorang untun merokok. Adanya krisis psikososial berupa simbolisasi diri bahwa merokok merupakan symbol kematangan, kekuatan, dan daya tarik terhadap lawan jenis melatar belakangi seseorang untuk merokok (Amelia dalam Komalasari, 2000).

Asap rokok mengandung sekitar 4000 senyawa kimia yang secara farmakologis terbukti aktif, beracun, dapat menyebabkan mutasi (mutagenic), dan kanker (carcinogenic). Tiga racun utama dalam rokok yaitu nikotin, tar, dan karbon monoksida (Plus Redaksi, 2007).

Merokok merupakan salah satu faktor resiko dari berbagai penyakit seperti gangguan pernapasan, seperti nyeri di paru-paru, batuk kering, dan infeksi saluran pernapasan, serangan jantung, stroke, kanker impotensi, dan gangguan kehamilan (Sukmana Teddie, 2009). Dalam penelitian beberapa tahun terakhir, dikemukakan bahwa merokok juga dapat memengaruhi komponenkomponen darah. Misalnya, pengaruh rokok pada jumlah sel darah putih (leukosit) yang menunjukkan bahwa terdapat peningkatan sel darah putih pada perokok daripada bukan perokok. Merokok juga diduga dapat terpengaruh pada komponen darah lainnya, misalnya eritrosit, trombosit, hemoglobin, dan sebagainya

(Wibowo dalam Islam, 2007).

Hemoglobin adalah suatu protein tetrametrik dalam eritrosit yang berikatan dengan oksigen serta bertugas dalam melepaskan oksigen tersebut kedalam jaringan. Selain itu, hemoglobin juga nantinya akan berikatan dengan karbon dioksida untuk mengembalikannya ke paru (Wibowo Granner dkk, 2009). Karbon monoksida (CO) yang terkandung dalam rokok memiliki afinitas yang besar terhadap hemoglobin sekitar 210-300 kali lebih besar dibandingkan dengan afinitas terhadap oksigen, sehingga memudahkan keduanya untuk saling berikatan 
karboksihemoglobin, suatu bentuk inaktif dari hemoglobin. Hal ini mengakibatkan hemoglobin tidak dapat mengikat oksigen untuk dilepaskan ke berbagai jaringan sehingga menimbulkan terjadinya hipoksia jaringan. Tubuh manusia akan berusaha mengkompensasi penurunan kadar oksigen dengan cara meningkatkan kadar hemoglobin (Wibowo dalam Leifert JA, 2008).

Fakta mengatakan bahwa perokok bernafas pada $250 \mathrm{ml} \mathrm{CO}$ dari setiap bungkus rokok. $\mathrm{CO}$ mengurangi kemampuan eritrosit untuk membawa oksigen dan tubuh mengkompensasi hal ini juga dengan memproduksi lebih banyak eritrosit yang dapat menyebabkan polisitemia. (Irawati dalam Cameron, 2011).

Polisitemia adalah suatu keadaan dimana terjadi peningkatan jumlah sel darah merah akibat pembentukan sel darah merah yang berlebihan oleh sumsung tulang.

Polisitemia adalah suatu kondisi yang jarang terjadi di mana tubuh terlalu banyak memproduksi sel darah merah. Orang dengan polisitemia memiliki peningkatan hematokrit, hemoglobin, atau jumlah sel darah merah di atas batas normal melebihi 6 juta/mm atau hemoglobinnya melebihi $18 \mathrm{gr} / \mathrm{dl}$. Meningkatnya jumlah sel darah merah dalam sirkulasi darah, viskositas darah total, merupakan peristiwa yang menyebabkan melambatnya aliran darah dan merupakan penyebab dari manifestasi patofisiologi penyakit ini. Meningkatnya viskositas darah megakibatkan peningkatan volume darah dan selanjutnya diikuti meningkatnya kerja jantung, vasodilatasi serta meningkatnya oksigen ke jaringan (Sari Sinta, 2014).

Semakin besar persentase sel dalam darah, artinya semakin besar hematokrit semakin banyak gesekan yang terjadi antara berbagai lapisan darah, dan gesekan ini menentukan viskositas. Karena itu, viskositas darah meningkat hebat dengan meningkatnya hematokrit (Irawati dalam Guyton, 2010).

Penelitian yang dilakukan Cholid (2011), terhadap orang yang perokok, mendapatkan hasil bahwa terdapat pengaruh antara kebiasaan merokok dengan viskositas darah melalui pemeriksaan hematokrit.

Penelitian yang dilakukan Bjork pada tahun 2000, mendapatkan hasil bahwa kebiasaan merokok menyebabkan penurunan kadar $\mathrm{Hb}$ darah, tetapi penelitian Odenberg dan W. Adamson pada tahun 2005 menyatakan bahwa merokok menyebabkan terjadinya peningkatan kadar $\mathrm{Hb}$ darah. Berdasarkan informasi tersebut bahwa merokok mempunyai hubungan dengan kadar $\mathrm{Hb}$ darah di dalam tubuh (Pratiwi, 2015).

\section{METODE}

Jenis penelitian yang akan dilakukan adalah observasi laboratorium dengan pendekatan cross sectional untuk mengetahui hubungan kadar hemoglobin dan hematokrit pada perokok aktif.

Penelitian ini dilaksanakan di Balai Besar Laboratorium Kesehatan Makassar pada bulan Maret 2019. Sampel yang digunakan yaitu perokok aktif yang sesuai dengan kriteria inklusi.

Alat penelitian yang digunakan adalah: spoit $3 \mathrm{ml}$, vacumtainer EDTA, kapas alkohol, tourniquet, masker, handscoon alat Mindray BC-5300. Bahan penelitian yang digunakan yaitu darah dan reagen hematologi analyzer Mindray BC-5300.

Prosedur Kerja

1. Tahap Pra-Analitik

Persiapan pasien mulai mengisi infornt consent. Prinsip Mindray BC5300: Mengukur sel darah secara 
otomatis berdasarkan impedansi aliran listrik atau berkas cahaya terhadap selsel yang dilewatkan atau pengukuran dan penyerapan sinar akibat interaksi sinar yang mempunyai panjang gelombang tertentu dengan larutan atau sampel yang dilewatinya. Alat ini bekerja berdasarkan prinsip flow sytometer. Flow cytometer adalah metode pengukuran (metri) jumlah dan sifat-sifat sel (cyto) yang dibungkus oleh cairan (flow) melalui celah sempit. Ribuan sel dialirkan melalui celah tersebut sedemikian rupa sehingga sel dapat lewat satu per satu, kemudian dilakukan perhitungan jumlah sel dan ukurannya. Alat ini juga memberikan informasi intra seluler, termasuk inti sel.

a. Alat dan bahan

Alat Mindray BC-5300, sedangkan bahan yang digunakan diantaranya antikoagulan (EDTA), kapas alkohol, spoit $3 \mathrm{ml}$, tourniquet, dan plaster.

2. Tahap Analitik

a. Prosedur pengambilan darah vena

Pasien dalam keadaan duduk. Letakkan tangan pasien lurus dengan telapak tangan menghadap ke atas. Vena pasien dibendung dengan tourniquet, kemudian pasien disuruh mengapalkan tangan beberapa kali untuk mengisi pembuluh darah. Ujung telunjuk kiri memeriksa lokasi vena yang akan ditusuk. Setelah didapat, vena pasien didesinfektan dengan kapas alkohol $70 \%$ dan dibiarkan kering. Tusuk vena pasien dengan spoit dengan arah lubang jarum menghadap ke atas. Mintalah kepada pasien untuk membuka kepalan tangannya saat darah dihisap kedalam spoit. Lepaskan tourniquet dan letakkan kapas kering pada tempat penusukan lalu diberi plester. Jarum dilepas dari spoit, lalu darah dimasukkan kedalam tabung EDTA. Spoit yang telah digunakan segera dibuang pada tempat pembuangan khusus. b. Pemeriksaan hemoglobin dan hematokrit dengan menggunakan alat Mindray BC-5300.

Nyalakan komputer dan masuk di menu utama Mindray BC-5300. Nyalakan alat Mindray BC-5300 dengan cara menekan tombol ON pada power di samping bagian belakang alat. Klik yes apabila muncul note "Skip Fluidics

Initalization". Klik Worklist (new, save, run), untuk mengisi ID dan Identitas pasien. Baca sampel darah EDTA pasien dengan cara memasukkan jarum aspirate ke dalam sampel yang terlebih dahulu di homogenkan, lalu tekan aspiratnya. Klik Graph untuk melihat hasil pemeriksaan. Pilih menu print pada graph untuk mencetak sebagai print out.

3. Tahap Pasca Analitik Interpretasi hasil kadar $\mathrm{Hb}$ dan Ht pada perokok aktif. Nilai normal hemoglobin : Pria 13-18 g/dL dan pada wanita 12-16 $\mathrm{g} / \mathrm{dL}$. Nilai normal hematokrit : Pria: 40-48\% dan Wanita : 37-43\% (Arianda Dedy, 2017)

\section{Analisis Data}

Analisis data disajikan dalam bentuk table dan dianalisa dengan melihat hasil korelasi, berdasarkan rumus Uji Korelasi Person.

\section{HASIL}

Berdasarkan hasil penelitian yang dilakukan di Balai Besar Kesehatan Paru Masyarakat Makassar pada bulan Maret 2019, dengan hasil sebagai berikut Dari hasil penelitian yang diperoleh seperti yang tercantum pada tabel 01 selanjutnya diolah dengan teknik analisa data secara deskriptif. Tabel 02 menunjukkan bahwa dari 33 sampel ditemukan 0 sampel $(0 \%)$ dengan kadar hemoglobin tinggi, 18 sampel (54.54\%) dengan kadar hemoglobin normal, dan 15 sampel (45.45\%) dengan kadar hemoglobin 
rendah. Tabel 03 menunjukkan bahwa dari 33 sampel ditemukan 4 sampel (12.12\%) dengan kadar hematokrit tinggi, 14 sampel $(42.42 \%)$ dengan kadar hematokrit normal, dan 15 sampel (45.45\%) dengan kadar hematokrit rendah. Selanjutnya dari data hasil penelitian yang diperoleh seperti yang tercantum pada tabel 1 dilakukan analisa dengan melihat hasil korelasi, berdasarkan rumus Uji Korelasi Person : Karena $\mathrm{r}$ hitung $(0.93)>\mathrm{r}$ tabel (0.344), maka $\mathrm{H}_{0}$ di tolak. Kesimpulan ada hubungan yang bermakna antara hemoglobin dan hematokrit para perokok tif. Hemoglobin berhubungan secara positif terhadap hematokrit dengan derajat hubungan korelasi kuat.

\section{PEMBAHASAN}

Hemoglobin adalah suatu protein tetrametrik dalam eritrosit yang berikatan dengan oksigen serta bertugas dalam melepaskan oksigen tersebut ke jaringan. Selain itu hemoglobin juga nantinya akan berikatan dengan karbon dioksida untuk mengembalikannya ke paru (Wibowo D.V dalam Granner dkk, 2017). Seharusnya, hemoglobin ini berikatan dengan oksigen yang sangat penting untuk pernapasan sel-sel tubuh, tetapi karena gas $\mathrm{CO}$ lebih kuat dari pada oksigen, maka gas $\mathrm{CO}$ ini merebut tempatnya "disis" hemoglobin. Jadilah, hemoglobin bergandengan dengan gas CO. kadar gas $\mathrm{CO}$ dalam darah bukan perokok kurang dari $1 \%$, sementara dalam darah perokok mencapai $4-15 \%$. Karena $\mathrm{CO}$ mengurangi kemampuan eritrosit untuk membawa oksigen maka tubuh mengkompensasi hal ini dengan memproduksi lebih banyak eritrosit yang mengakibatkan polisitemia (Amelia dalam Leifert, 2016).

Polisitemia adalah suatu kondisi yang jarang terjadi di mana tubuh terlalu banyak memproduksi sel darah merah. Orang dengan polisitemia memiliki peningkatan hematokrit, hemoglobin, atau jumlah sel darah merah di atas batas normal melebihi 6 juta/mm atau hemoglobinnya melebihi $18 \mathrm{gr} / \mathrm{dl}$. Meningkatnya jumlah sel darah merah dalam sirkulasi darah, viskositas darah total, merupakan peristiwa yang menyebabkan melambatnya aliran darah dan merupakan penyebab dari manifestasi patofisiologi penyakit ini. Meningkatnya viskositas darah megakibatkan peningkatan volume darah dan selanjutnya diikuti meningkatnya kerja jantung, vasodilatasi serta meningkatnya oksigen ke jaringan (Sari Sinta, 2014).

Semakin besar persentase sel dalam darah, artinya semakin besar hematokrit semakin banyak gesekan yang terjadi antara berbagai lapisan darah, dan gesekan ini menentukan viskositas. Karena itu, viskositas darah meningkat hebat dengan meningkatnya hematokrit (Irawati dalam Guyton, 2010).

Berdasarkan hasil penelitian dengan menggunakan teknik analisa data secara deskriptif didapatkan hasil dari 33 sampel ditemukan 0 sampel (0\%) dengan kadar hemoglobin tinggi, 18 sampel (54.54\%) dengan kadar hemoglobin normal, dan 15 sampel (45.45\%) dengan kadar hemoglobin rendah. Hasil penelitian yang dilakukan oleh Shah et al (2012) mendapatkan kadar hemoglobin pada perokok lebih tinggi jika dibandingkan dengan non perokok. Pada penelitian yang dilakukan oleh Bashir et al (2016) dilaporkan juga peningkatan kadar hemoglobin yang berkorelasi dengan peningkatan ukuran eritrosit pada perokok jika dibandingkan dengan bukan perokok.

Perbedaan ini dapat disebabkan karena kadar hemoglobin setiap individu dipengaruhi oleh banyak faktor 
seperti umur, jenis kelamin, nutrisi, aktivitas fisik, ketinggian daerah tempat tinggal, kebiasaan merokok, obat obatan yang di konsumsi, serta alat dan metode tes yang di gunakan. Penelitian ini tidak bisa mengontrol status nutrisi dan aktivitas fisik dari responden, sehingga dapat mengganggu nilai dari kadar hemoglobin responden tersebut.

Hasil penelitian nilai hematokrit terhadap perokok aktif juga menggunakan teknik analisa data secara deskriptif menunjukkan bahwa dari 33 sampel ditemukan 4 sampel $(12.12 \%)$ dengan kadar hematokrit tinggi, 14 sampel (42.42\%) dengan kadar hematokrit normal, dan 15 sampel $(45.45 \%)$ dengan kadar hematokrit rendah.

Nilai hematokrit berkorelasi positif dengan kadar viskositas darah, semakin tinggi nilai hematokrit maka kadar viskositas darah juga akan semakin meningkat. Hasil penelitian yang dilakukan oleh Irawati, Lili (2011) menunjukkan bahwa tidak ada hubungan yang bermakna antara jumlah rokok yang dihisap perhari dengan viskositas darah. Hasil penelitian yang dilakukan oleh Cholid (2011), bahwa terdapat pengaruh antara kebiasaan merokok dengan viskositas darah melalui pemeriksaan hematokrit terhadap orang yang perokok aktif.

Perbedaan ini dapat disebabkan karena kadar hematokrit setiap individu dipengaruhi oleh banyak faktor diantaranya perubahan cairan plasma seperti kasus dehidrasi, penurunan atau peningkatan jumlah sel terutama eritrosit, dan sebagainya.

Pada penelitian ini untuk menganalisa hubungan antara kadar hemoglobin dan nilai hematokrit digunakan uji korelasi person dengan hasil nilai $r$ hitung $(0,93)>$ dari nilai $r$ tabel (0.344) yang berarti $\mathrm{H}_{\mathrm{o}}$ di tolak, menunjukkan bahwa terdapat hubungan yang bermakna antara kadar hemoglobin dan nilai hematokrit pada perokok aktif.

Hal ini telah dibuktikan pada penelitian sebelumnya yang dilakukan oleh Anggraini 2010, yang menyebutkan bahwa ada hubungan atau korelasi antara kadar hemoglobin dengan jumlah eritrosit terhadap perokok aktif. Selain itu peningkatan jumlah eritrosit ini berkorelasi positif terhadap nilai hematokrit. Semakin besar jumlah eritrosit, maka semakin besar pula nilai hematokrit dalam darah, begitupun sebaliknya. Nilai hematokrit sangat tergantung pada jumlah eritrosit, karena eritrosit merupakan massa sel terbesar dalam darah.

\section{KESIMPULAN}

Berdasarkan penelitian yang telah dilakukan di Balai Besar Kesehatan Paru Masyarakat Makassar dengan 33 jumlah sampel didapatkan kesimpulan sebagai berikut terdapat hubungan antara kadar hemoglobin dan hematokrit pada perokok aktif. Hemoglobin berhubungan secara positif terhadap hematokrit.

\section{SARAN} berikut

Adapun beberapa saran sebagai

1. Bagi peneliti selanjutnya, dianjurkan untuk meneliti faktor faktor yang dapat mempengaruhi kadar hemoglobin dan hematokrit dalam darah selain disebabkan oleh merokok.

2. Bagi masyarakat umum hendaknya dapat memberikan informasi yang lebih banyak tentang bahaya merokok melalui media massa dan cetak atau propaganda kepada masyarakat khususnya tentang kandungan-kandungan zat kimia yang ada didalam rokok beserta dampaknya terhadap tubuh. 
DAFTAR PUSTAKA

Amelia, Rizky Nazrul, Ellyza Basyar, Masrul, 2016. Hubungan Derajat Merokok Berdasarkan Indeks Brinkman dengan Kadar Hemoglobin. http://jurnal.fk.unand.ac.id/in dex.php/jka/article/viewFile/5 $\underline{87 / 475}$ di akses 1, Januari 2019.

Arianda Dedy. 2017. Buku Saku Analis Kesehatan. Bekasi; Analis Muslim Publisher

Bakta, Made. 2006. Hematologi Klinik Ringkas. Jakarta. EGC.

Beni Kasem, 2017. Gambaran Hemoglobin pada perokok aktif lansia di R.S.U Wisata Universitas Indonesia Timur.

Darmawan M.E dalam siti, 2017. Pengaruh Waktu Centrifugasi Terhadap Hasil Pemeriksaan HCT Metode Makro (Manual) Di Laboratorium Analis Kesehatan Universitas Indonesia Timur Makassar.

Hoffbrand A.V. Moss, P.A.H. 2016. Kapita Selekta Hematologi Edisi 6. Jakarta; EGC.

Hoffbrand A.V. Pettit,J.E P. Moss, P.A.H. 2005. Kapita Selekta Hematologi. Jakarta; EGC.

Ikadek, 2018. Gambaran Hasil Peningkatan Kadar Hemoglobin Pada Pasien Anemia Yang Ditransfusi Dengan Picked Red Cell Dan Whole Blood Di Rsud Kabupaten Polewali Mandar.

Jaya Muhammad, 2009. Pembunuh Berbahaya Itu Bernama Rokok. Yogyakarta; Rizma

Kementerian Kesehatan RI, 2017. Hidup Sehat Tanpa Merokok. Jakarta

Kiswari. 2014. Hematologi dan Transfusi. Jakarta; Erlangga
Mawakes M.T, Kalangi S.J, Pasiak T.F, 2016. Perbandingan Kadar Hemoglobin Darah Pada Pria Perokok Dan Bukan Perokok https://ejournal.unsrat.ac.id/i ndex.php/ebiomedik/article/d ownload/11250/10841 di akses tanggal 12 Januari 2019.

Pratiwi N.A, 2015. Gambaran Hemoglobin Pada Perokok Di Kampong Adat Cireundu http://repository.poltekkesbdg info/items/show/549 di akses tanggal 12 Januari 2019.

Priskilla, 2015. Pengendalian Perilaku Merokok.

http://www.google.com/url?s $a=t \& r c t=j \& q=\& e s r c=s \&$ sou $r c e=w e b \& c d=$ di akses tanggal 7 Januari 2019.

Ronald A., McPherson Richard A. 2004. Tinjauan Klinis Hasil Pemeriksaan Laboratorium. Jakarta; EGC.

Sadikin, Mohammad. 2008. Seri Biokimia, Biokimia Darah, Jakarta, Widya Medika.

Tarwoto. Wartonan, 2008. Keperawatan Medikal Bedah Gangguan Sistem Hematologi. Jakarta; Trans Info Media.

Wibowo D, Pangemanan D, Polii H, dalam RISKESDAS 2017. Hubungan Kasar Hemoglobin dan Trombosit pada Perokok Dewasa https://ejournal.unsrat.ac.id/in dex.php/ebiomedik/article/vie wFile/18510/18038 di akses tanggal 10 Januari 2019.

Zulfikri, 2018. Studi Pemeriksaan Hematokrit Pada Orang Yang Berpuasa Di Laboratorium Rumah Sakit Umum Wisata Universitas Indonesia Timur. 
Tabel 01.

Hasil Pemeriksaan Kadar Hemoglobin dan Nilai Hematokrit pada Perokok Aktif

\begin{tabular}{|c|c|c|c|c|c|c|c|c|c|}
\hline No & JK & Umur & $\begin{array}{l}\text { Hemoglo } \\
\text { bin }(\mathrm{g} / \mathrm{dl})\end{array}$ & $\begin{array}{c}\text { Hematok-rit } \\
(\%)\end{array}$ & No & JK & Umur & $\begin{array}{l}\text { Hemoglo } \\
\text { bin (g/dl) }\end{array}$ & $\begin{array}{c}\text { Hematokrit } \\
(\%)\end{array}$ \\
\hline 1 & $\mathrm{~L}$ & 40 & 14.4 & 42.1 & 18 & $\mathrm{~L}$ & 63 & 15 & 43.1 \\
\hline 2 & $\mathrm{~L}$ & 50 & 11.9 & 36.5 & 19 & $\mathrm{~L}$ & 47 & 15.1 & 45.2 \\
\hline 3 & $\mathrm{~L}$ & 56 & 14.1 & 40.7 & 20 & $\mathrm{~L}$ & 45 & 12.7 & 37.8 \\
\hline 4 & $\mathrm{~L}$ & 35 & 13.1 & 38 & 21 & $\mathrm{~L}$ & 54 & 14.8 & 44.2 \\
\hline 5 & $\mathrm{~L}$ & 63 & 11.5 & 34.5 & 22 & $\mathrm{~L}$ & 52 & 16.4 & 47.8 \\
\hline 6 & $\mathrm{~L}$ & 19 & 13.5 & 39 & 23 & $\mathrm{~L}$ & 29 & 11.5 & 33.7 \\
\hline 7 & $\mathrm{~L}$ & 47 & 12.7 & 38.6 & 24 & $\mathrm{~L}$ & 41 & 16.1 & 48.8 \\
\hline 8 & $\mathrm{~L}$ & 49 & 16.8 & 50.1 & 25 & $\mathrm{~L}$ & 49 & 14.8 & 44.7 \\
\hline 9 & $\mathrm{~L}$ & 39 & 14.1 & 39.6 & 26 & $\mathrm{~L}$ & 40 & 16.4 & 47.1 \\
\hline 10 & $\mathrm{~L}$ & 52 & 15.5 & 45.1 & 27 & $\mathrm{~L}$ & 20 & 13.5 & 39.3 \\
\hline 11 & $\mathrm{~L}$ & 24 & 13 & 37.8 & 28 & $\mathrm{~L}$ & 50 & 15.8 & 45.2 \\
\hline 12 & $\mathrm{~L}$ & 70 & 16.1 & 48.6 & 29 & $\mathrm{~L}$ & 57 & 15.4 & 45.9 \\
\hline 13 & $\mathrm{~L}$ & 40 & 15.3 & 45.3 & 30 & $\mathrm{~L}$ & 20 & 16.2 & 48.2 \\
\hline 14 & $\mathrm{~L}$ & 15 & 13.3 & 39.5 & 31 & $\mathrm{~L}$ & 28 & 14.4 & 43.6 \\
\hline 15 & $\mathrm{~L}$ & 27 & 13.5 & 38.8 & 32 & $\mathrm{~L}$ & 54 & 15 & 35.9 \\
\hline 16 & $\mathrm{~L}$ & 71 & 13 & 39 & 33 & $\mathrm{~L}$ & 63 & 12.5 & 40.2 \\
\hline 17 & $\mathrm{~L}$ & 50 & 9.2 & 28.3 & & & & & \\
\hline
\end{tabular}

Tabel 02.

Hasil persentase kadar hemoglobin terhadap perokok aktif

\begin{tabular}{lcc}
\hline \multicolumn{1}{c}{ Jenis Pemeriksaan Darah } & Frekuensi & Persentase (\%) \\
\hline Hemoglobin Tinggi & 0 & 0 \\
Hemoglobin Normal & 18 & 54.54 \\
Hemoglobin Rendah & 15 & 45.45 \\
\hline Total & 33 & 100 \\
\hline
\end{tabular}

Tabel 03.

Hasil persentase nilai hematokrit terhadap perokok aktif

\begin{tabular}{lcc}
\hline \multicolumn{1}{c}{ Jenis Pemeriksaan Darah } & Frekuensi & Persentase (\%) \\
\hline Hematokrit Tinggi & 4 & 12.12 \\
Hematokrit Normal & 14 & 42.42 \\
Hematokrit Rendah & 15 & 45.45 \\
\hline Total & 33 & 100 \\
\hline
\end{tabular}

